\title{
Antiinflammatory Effect of Mace, Aril of Myristica fragrans HoutT., and Its Active Principles
}

\author{
Yukihiro OZAKI, Soekeni SOEDIGDO ${ }^{1}$, Yoke Rosina WATTIMENA' \\ and Asep Gana SUGANDA ${ }^{1}$ \\ Division of Pharmacognosy and Phytochemistry, National Institute \\ of Hygienic Sciences. Tokyo 158, Japan \\ 1 Department of Pharmacy, Institute Technology of Bandung. Bandung, Indonesia
}

Accepted October 14, 1988

\begin{abstract}
Mace which is the aril of the fruit of Myristica fragrans HOUTT. has been used in Indonesian folk medicine as aromatic stomachics, analgesics, a medicine for rheumatism, etc. The present study was carried out to elucidate the antiinflammatory effect of methanol extract obtained from Mace and its active principles. The methanol extract was extracted with ether, and then the ether soluble fraction was extracted with $n$-hexane. The $n$-hexane soluble fraction was fractionated by silica gel column chromatography ( Fr-I-Fr-V), and the active principle was isolated from $\mathrm{Fr}-\mathrm{II}$ by thin layer chromatography (Fr-VI-Fr-VII). The antiinflammatory activity of these fractions was investigated on carrageenin-induced edema in rats and acetic acid-induced vascular permeability in mice. All fractions and indomethacin were suspended in $2 \%$ C.M.C. solution and administered p.o. The methanol extract $(1.5 \mathrm{~g} / \mathrm{kg})$, ether fraction $(0.9 \mathrm{~g} / \mathrm{kg})$, $\mathrm{n}$-hexane fraction $(0.5$ $\mathrm{g} / \mathrm{kg})$. Fr-II $(0.19 \mathrm{~g} / \mathrm{kg})$ and $F r-V I(0.17 \mathrm{~g} / \mathrm{kg})$ showed a lasting antiinflammatory activity, and the potencies of these fractions were approximately the same as that of indomethacin $(10 \mathrm{mg} / \mathrm{kg})$. Fr-VI was determined to be myristicin. These results suggest that the antiinflammatory action of Mace is due to the myristicin that it contains.
\end{abstract}

Nutmeg which is the seed of Myristica fragrans HOUTT. is used in Chinese medicine as aromatic stomachics, analgesics, and a medicine for diarrhea (1-6), and many pharmacological studies on it have been reported (7-12).

Mace, a common spice, which is the aril surrounding the shell enclosing the seed, has been used in Indonesian folk medicine as aromatic stomachics, analgesics and a medicine for rheumatism (1-5). Although, some pharmacological studies on the methanol extract of Mace have been reported $(13,14)$. there have been very few antiinflammatory studies on it.

On the basis of these uses in folk medicine, the present study was carried out to elucidate the antiinflammatory effect of a $70 \%$ methanol extract obtained from Mace and its active principles (15).

\section{Materials and Methods}

1. Preparation of materials: Crude powder of Mace was refluxed with $70 \%$ methanol for $6 \mathrm{hr}$, three times. The solution was filtered through filter paper and evaporated to give an oily extract under vacuum. The extract was dissolved in ether and extracted with water three times. The ether phase was separated and evaporated to dryness under vacuum. The ether soluble fraction was dissolved in $n$-hexane and extracted with methanol three times. The $n$-hexane phase was separated and evaporated to dryness under vacuum. The $n$-hexane soluble fraction was chromatographed on a silica gel column, using the elution solvent of $n$-hexane, benzene, ethylacetate and methanol.

Each fraction was evaporated to dryness under vacuum and assayed for its antiinflam- 
matory effect. The methanol extract, each fraction, and indomethacin (Sigma) were suspended in $2 \%$ C.M.C. solution. The dose for each of the fractions was derived based on yields obtained from the methanol extraction.

2. Carrageenin induced hind-paw edema: Male Wistar rats weighing 200-250 g were fasted $16 \mathrm{hr}$ prior to experiments, but were supplied with water ad libitum. Carrageenin (Picnin-A, Zushikagaku Lab., Inc.) was suspended in saline to make a $1 \%(\mathrm{~W} / \mathrm{V})$ suspension. The suspension of carrageenin was injected subcutaneously into the right hindpaw 30 min after the test solutions had been administered orally.

The volume of hind-paw was measured before the test solutions had been administered by a water displacement transducer (LPU-0.1A. Nihon Kohden). The swelling hind-paw volumes were measured $30 \mathrm{~min}$ and $1 \mathrm{hr}$ after the suspension of carrageenin had been administered and then up to $6 \mathrm{hr}$ at intervals of $1 \mathrm{hr}$.

Control rats were treated similarly except that they received an oral dose of $2 \%$ C.M.C. solution alone. The results were expressed as the percent increase in hind-paw volume due to swelling, as compared with the initial hindpaw volume.

3. Acetic acid induced vascular permeability: Male ddY mice weighing $20-25 \mathrm{~g}$ were fasted $2 \mathrm{hr}$ prior to experiments, but were supplied, with water ad libitum. Four percent pontamine sky blue solution in saline $(\mathrm{w} / \mathrm{v})$ was injected intravenously into the tail vein 40 min after test solutions had been adminstered orally.

After $30 \mathrm{~min}, 1 \%$ acetic acid solution in saline $(v / v)$ was injected intraperitoneally; and then after $20 \mathrm{~min}$, mice were killed by dislocation of the neck, and the abdominal wall was cut to expose the entrails. After washing the entrails with saline, the washings were filtered through glasswool and collected into test tubes. To each tube was added 0.1 $\mathrm{ml}$ of $\mathrm{NaOH}$ solution in order to clear any turbidity due to protein, and the absorbance was read at $590 \mathrm{~nm}$ in a spectrophotometer (Model 200-10. Hitachi). Control mice were treated similarly, except that they received an oral dose of $2 \%$ C.M.C. solution alone.
The vascular permeability effects were expressed in terms of total dye ( $\mu \mathrm{g} / \mathrm{animal})$ amount which leaked into the intraperitoneal cavity.

4. Acetic acid induced writhing: Male ddY mice weighing 20-25 g were fasted $2 \mathrm{hr}$, but were supplied with water ad libitum. A $0.7 \%$ solution of acetic acid in saline $(\mathrm{V} / \mathrm{V})$ was injected intraperitoneally $85 \mathrm{~min}$ after the test solutions had been administered orally. After $5 \mathrm{~min}$, the number of writhings induced by the acetic acid solution were counted for $10 \mathrm{~min}$.

Control mice were treated similarly, except that they received an oral dose of $2 \%$ C.M.C. solution alone.

5. Statistical analysis: Data were expressed as the mean value \pm standard error. All results were analyzed by Student's $t$-test.

\section{Results}

1. Effect of methanol extract obtained from Mace: The methanol extract, $1.5 \mathrm{~g} / \mathrm{kg}$. showed a lasting inhibition on the edema induced by carrageenin during $6 \mathrm{hr}$, except at 0.5 and $2 \mathrm{hr}$, after injection of carrageenin. The inhibitory potency induced by the methanol extract was about the same as that of $10 \mathrm{mg} / \mathrm{kg}$ of indomethacin, as shown in Fig. 1 .

The methanol extract, $1 \mathrm{~g} / \mathrm{kg}$, inhibited the increase of dye leakage induced by acetic acid. Indomethacin at $10 \mathrm{mg} / \mathrm{kg}$ inhibited the dye leakage, and the inhibitory potency was about the same as that of the methanol extract, $1 \mathrm{~g} / \mathrm{kg}$, as shown in Table 1 .

The methanol extract, 0.3 and $1 \mathrm{~g} / \mathrm{kg}$. reduced the number of writhings induced by acetic acid. The inhibitory potency induced by the extract, $1 \mathrm{~g} / \mathrm{kg}$. Was more potent than that of $10 \mathrm{mg} / \mathrm{kg}$ of indomethacin, as shown in Table 2.

2. Fractionation of methanol extract obtained from Mace: As shown in Fig. 2, the methanol extract was partitioned between ether and water. A portion of the ether soluble fraction was separated into $n$-hexane and methanol soluble fractions.

The $n$-hexane soluble fraction was separated into fraction-I-fraction-V (Fr-I-Fr-V). Yields (\%) were calculated on the basis of the methanol extract obtained from Mace.

3. Effects of each fraction obtained from methanol extract: The ether soluble fraction. 

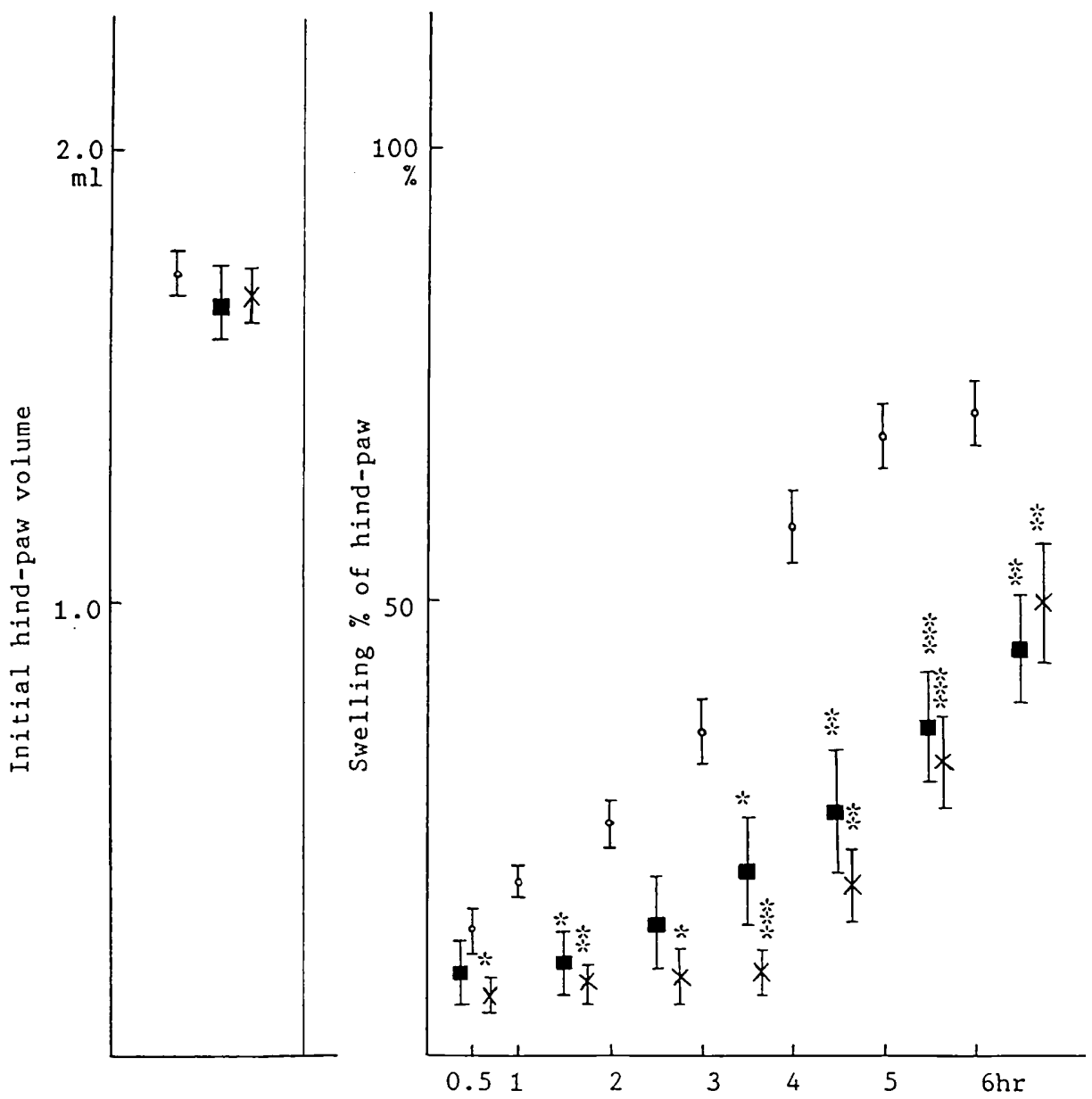

Fig. 1. Effect of the methanol extract obtained from Mace and indomethacin on the paw edema induced by carrageenin in rats. The results were expressed as the percent increase in hind-paw volume due to swelling (\%) (Iight column), as compared with the initial hind-paw volume ( $\mathrm{ml}$ ) before carrageenin injection (left column). $O$ : control (2\% C.M.C.) (p.c.) $(\mathrm{N}=7)$, $M$. fragrans $1.5 \mathrm{~g} / \mathrm{kg}(\mathrm{N}=7) . \times$ : indomethacin $10 \mathrm{mg} / \mathrm{kg}(\mathrm{N}=7)$. ${ }^{*} \mathrm{P}<0.05$, " $\mathrm{P}<0.01$, ${ }^{* *} \mathrm{P}<0.001$, when compared with control value.

Table 1. Effect of the methanol extract obtained from Mace and indomethacin on the increased vascular permeability induced by acetic acid in mice

\begin{tabular}{|c|c|c|c|}
\hline Compounds & $\begin{array}{c}\text { Dose } \\
(\mathrm{g} / \mathrm{kg}, \text { p.o.) }\end{array}$ & $\begin{array}{l}\text { No. of } \\
\text { animals }\end{array}$ & $\begin{array}{l}\text { Amount of } \\
\text { leaked dye } \\
(\mu \mathrm{g} / \text { animal) }\end{array}$ \\
\hline Contro! (2\% C.M.C.) & & 12 & $386.2 \pm 22.8$ \\
\hline \multirow[t]{2}{*}{ M. fragrans } & 0.3 & 6 & $362.2 \pm 29.8$ \\
\hline & 1 & 8 & $172.1 \pm 18.5^{* * *}$ \\
\hline Indomethacin & 0.01 & 8 & $23.8 .8 \pm 14.1^{* * *}$ \\
\hline
\end{tabular}


Table 2. Analgesic effect of the methanol extract obtained from Mace and indomethacin on the writhing symptom induced by acetic acid in mice

\begin{tabular}{lccc}
\hline Compounds & $\begin{array}{c}\text { Dose } \\
\text { (g/kg, p.o.) }\end{array}$ & $\begin{array}{c}\text { No. of } \\
\text { animals }\end{array}$ & $\begin{array}{c}\text { No. of } \\
\text { writhings } \\
\text { (for 10 min) }\end{array}$ \\
\hline Control (2\% C.M.C.) & & 10 & $39.2 \pm 1.9$ \\
M. fragrans & 0.3 & 7 & $29.3 \pm 3.9^{*}$ \\
Indomethacin & 1 & 8 & $18.9 \pm 3.3^{* * *}$ \\
\hline
\end{tabular}

${ }^{*} P<0.05,{ }^{* * P} P<0.01,{ }^{* * *} P<0.001$.

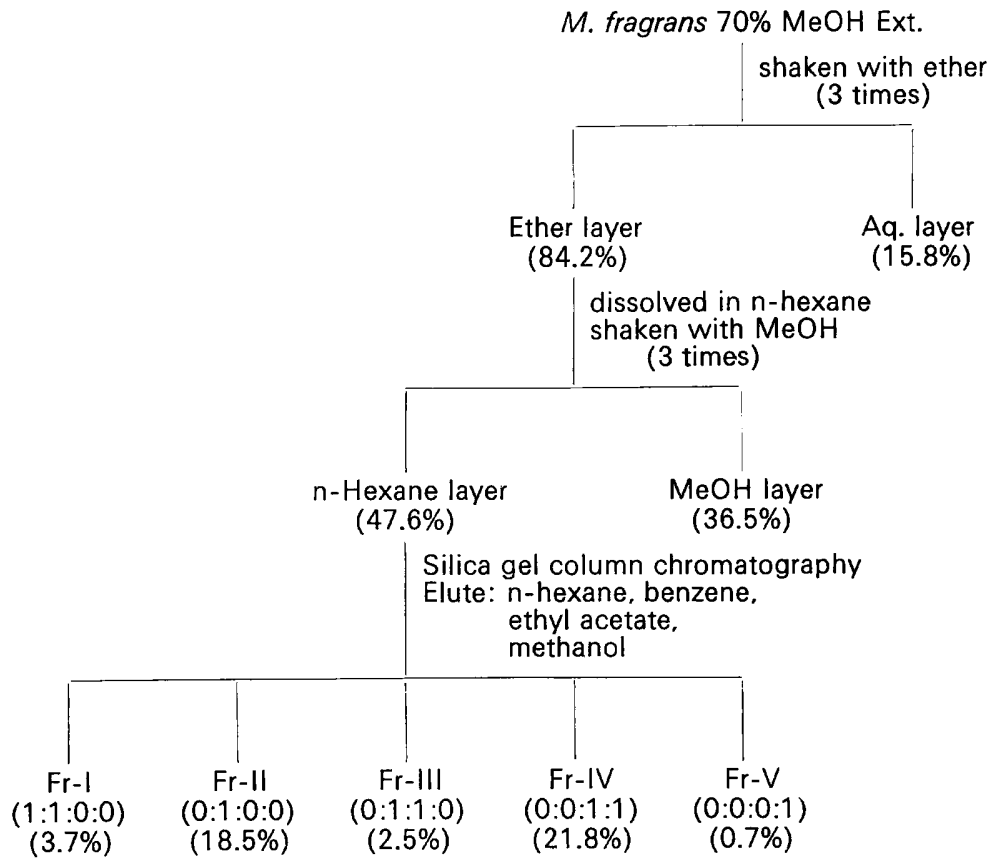

Fig. 2. Flow diagram of fractions of the methanol extract obtained from Mace. (\%) indicated percentage of yields which was calculated on the basis of the methanol extract obtained from Mace.

$1.2 \mathrm{~g} / \mathrm{kg}$, showed a lasting inhibition of edema during $30 \mathrm{~min}$ to $6 \mathrm{hr}$ after injection of carrageenin. On the other hand, the water soluble fraction, $0.3 \mathrm{~g} / \mathrm{kg}$, did not significantly inhibit the edema induced by carrageenin, except at $3 \mathrm{hr}$. The inhibitory potency induced by the ether soluble fraction was about the same as that of $10 \mathrm{mg} / \mathrm{kg}$ of indomethacin, as shown in Fig. 3.

The ether soluble fraction, $0.9 \mathrm{~g} / \mathrm{kg}$, inhibited the increase of dye leakage induced by acetic acid. The water soluble fraction, 0.2 $\mathrm{g} / \mathrm{kg}$, did not inhibit the increase of dye leakage. The inhibitory potency induced by the ether soluble fraction was the same as that of $10 \mathrm{mg} / \mathrm{kg}$ of indomethacin, as shown in Table 3.

The $\mathrm{n}$-hexane soluble fraction, $0.5 \mathrm{~g} / \mathrm{kg}$, inhibited the increase of dye leakage induced by acetic acid, but the methanol soluble fraction, $0.4 \mathrm{~g} / \mathrm{kg}$, did not inhibit the increase of dye leakage. The inhibitory potency induced by the $n$-hexane soluble fraction was the same as that of $10 \mathrm{mg} / \mathrm{kg}$ of indomethacin, as shown in Table 4.

As shown in Table 5, among these frac- 

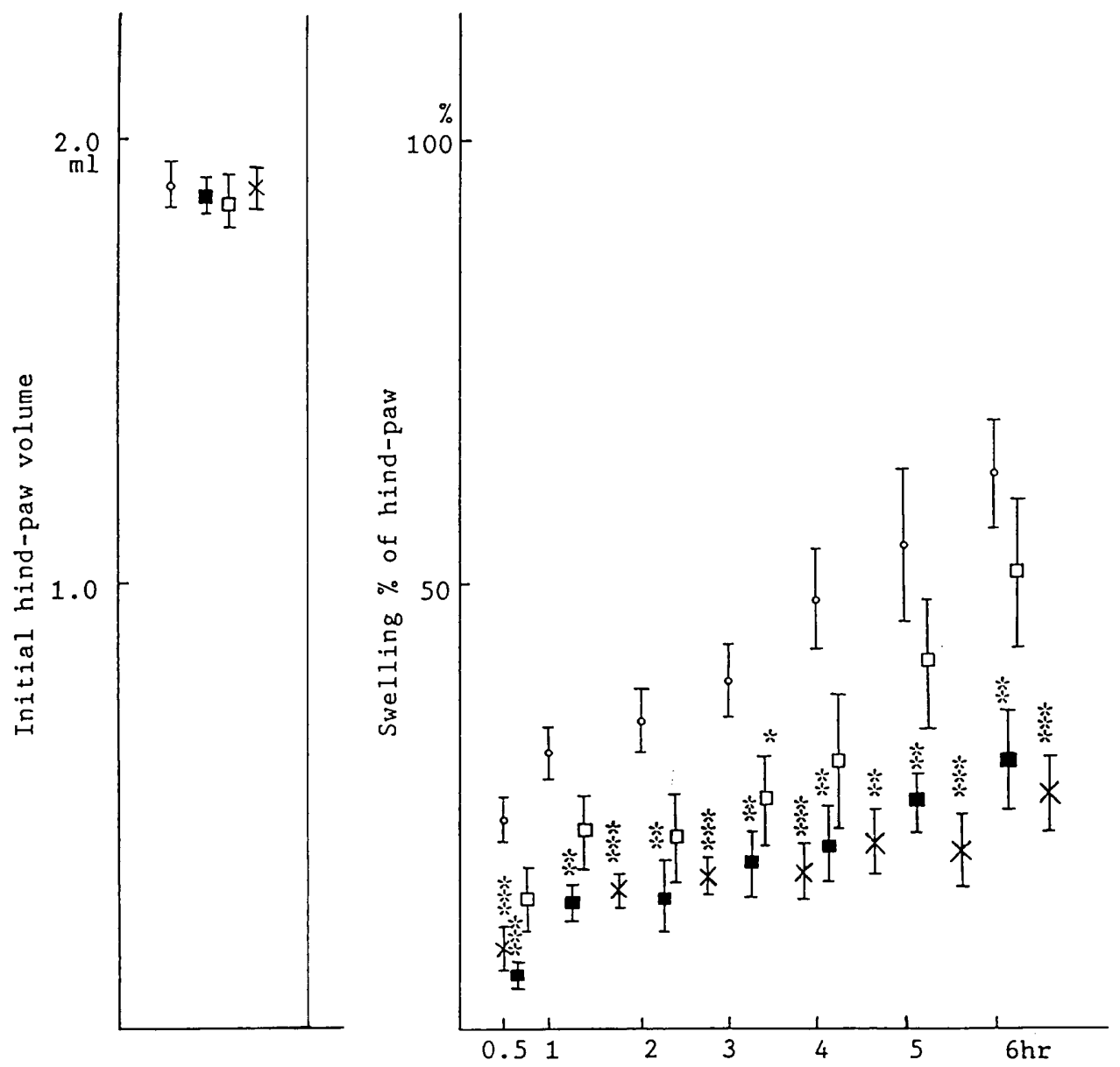

Fig. 3. Effect of the ether soluble fraction and the water soluble fraction obtained from the methanol extract and indomethacin on the paw edema induced by carrageenin in rats. The results were expressed as the percent increase in hind-paw volume due to swelling (\%) (right column), as compared with the initial hind-paw volume ( $\mathrm{ml}$ ) before carrageenin injection (left column). O: control ( $2 \%$ C.M.C.) (p.o.) $(\mathrm{N}=10)$. $\square$ : $M$. fragrans ether layer $1.2 \mathrm{~g} / \mathrm{kg}(\mathrm{N}=8), \square$ : $M$. fragrans aqueous layer $0.3 \mathrm{~g} / \mathrm{kg}(\mathrm{N}=8), \times$ : indomethacin $10 \mathrm{mg} / \mathrm{kg}(\mathrm{N}=10)$. ${ }^{*} P<0.05,{ }^{* *} \mathrm{P}<0.01,{ }^{* * *} \mathrm{P}<0.001$, when compared with control value.

Table 3. Effect of the ether soluble fraction and the water soluble fraction obtained from the methanol extract and indomethacin on the increased vascular permeability induced by acetic acid in mice

\begin{tabular}{ccccc}
\hline Compounds & $\begin{array}{c}\text { Yield } \\
(\%)\end{array}$ & $\begin{array}{c}\text { Dose } \\
(\mathrm{mg} / \mathrm{kg}, \mathrm{p} . \mathrm{o})\end{array}$ & $\begin{array}{c}\text { No. of } \\
\text { animals }\end{array}$ & $\begin{array}{c}\text { Amount of } \\
\text { leaked dye } \\
(\mu \mathrm{g} / \mathrm{animal})\end{array}$ \\
\hline Control (2\% C.M.C.) & & & 10 & $392.5 \pm 14.9$ \\
M. fragrans Ether layer & 84.2 & 0.9 & 8 & $200.2 \pm 11.2^{* * *}$ \\
Aq. layer & 15.8 & 0.2 & 8 & $375.5 \pm 20.3$ \\
Indomethacin & & 0.01 & 10 & $205.4 \pm 17.6^{* * *}$ \\
\hline
\end{tabular}

Yield (\%) indicated percentage of each yield obtained from the methanol extract. ${ }^{* * *} \mathrm{P}<0.001$. 
Table 4. Effect of the $n$-hexane soluble fraction and the methanol soluble fraction obtained from the ether fraction and indomethacin on the increased vascular permeability induced by acetic acid in mice

\begin{tabular}{|c|c|c|c|c|}
\hline Compounds & $\begin{array}{l}\text { Yield } \\
(\%)\end{array}$ & $\begin{array}{c}\text { Dose } \\
(\mathrm{mg} / \mathrm{kg}, \text { p.o. })\end{array}$ & $\begin{array}{l}\text { No. of } \\
\text { animals }\end{array}$ & $\begin{array}{l}\text { Amount of } \\
\text { leaked dye } \\
(\mu \mathrm{g} / \mathrm{animal})\end{array}$ \\
\hline Control ( $2 \%$ C.M.C.) & & & 16 & $439.2 \pm 19.2$ \\
\hline $\begin{array}{r}M . \text { fragrans } n-H e x a n e \text { layer } \\
\mathrm{MeOH} \text { layer }\end{array}$ & $\begin{array}{l}56.5 \\
43.4\end{array}$ & $\begin{array}{l}0.5 \\
0.4\end{array}$ & $\begin{array}{l}8 \\
8\end{array}$ & $\begin{array}{l}243.4 \pm 7.6^{* * *} \\
381.7 \pm 21.4\end{array}$ \\
\hline Indomethacin & & 0.01 & 14 & $274.9 \pm 25.8^{* * *}$ \\
\hline
\end{tabular}

Yield $(\%)$ indicated percentage of each yield obtained from the ether soluble fraction. ${ }^{* * *} \mathrm{P}<0.001$.

Table 5. Effect of fractions obtained from the $n$-hexane soluble fraction and indomethacin on the increased vascular permeability induced by acetic acid in mice

\begin{tabular}{|c|c|c|c|c|c|}
\hline \multicolumn{2}{|c|}{ Compounds } & $\begin{array}{c}\text { Yield } \\
(\%)\end{array}$ & $\begin{array}{c}\text { Dose } \\
\text { (mg/kg, p.o.) }\end{array}$ & $\begin{array}{r}\text { No. of } \\
\text { animals }\end{array}$ & $\begin{array}{l}\text { Amount of } \\
\text { leaked dye } \\
(\mu \mathrm{g} / \text { animal) }\end{array}$ \\
\hline \multicolumn{2}{|c|}{ Control ( $2 \%$ C.M.C.) } & & & 8 & $380.4 \pm 33.1$ \\
\hline \multirow[t]{5}{*}{ M. fragrans } & $\mathrm{Fr}-\mathrm{I}$ & 8.3 & 0.04 & 8 & $372.4 \pm 23.4$ \\
\hline & $\mathrm{Fr}-\mathrm{II}$ & 38.0 & 0.19 & 8 & $215.5 \pm 26.3^{* *}$ \\
\hline & Fr-1II & 6.3 & 0.03 & 8 & $310.5 \pm 16.5$ \\
\hline & Fr-IV & 45.8 & 0.23 & 8 & $338.8 \pm 19.4$ \\
\hline & $\mathrm{Fr}-\mathrm{V}$ & 1.6 & 0.01 & 8 & $368.7 \pm 31.2$ \\
\hline \multicolumn{2}{|c|}{ Indomethacin } & & 0.01 & 8 & $225.3 \pm 16.5^{* *}$ \\
\hline
\end{tabular}

Yield (\%) indicated percentage of each yield obtained from the $n$-hexane soluble fraction. ${ }^{* *} \mathrm{P}<0.01$.

Table 6. Effect of fractions obtained from the $n$-hexane soluble fraction and indomethacin on the writhing symptom induced by acetic acid in mice

\begin{tabular}{|c|c|c|c|c|c|}
\hline \multicolumn{2}{|c|}{ Compounds } & $\begin{array}{c}\text { Yield } \\
(\%)\end{array}$ & $\begin{array}{c}\text { Dose } \\
\text { (mg/kg, p.o.) }\end{array}$ & $\begin{array}{c}\text { No. of } \\
\text { animals }\end{array}$ & $\begin{array}{c}\text { No. of } \\
\text { writhings } \\
\text { (for } 10 \mathrm{~min} \text { ) }\end{array}$ \\
\hline \multicolumn{2}{|c|}{ Control (2\% C.M.C.) } & & & 8 & $38.6 \pm 1.5$ \\
\hline \multirow[t]{5}{*}{ M. fragrans } & $\mathrm{Fr}-\mathrm{I}$ & 8.3 & 0.04 & 8 & $32.1 \pm 3.7$ \\
\hline & $\mathrm{Fr}-\mathrm{II}$ & 38.0 & 0.19 & 8 & $20.6 \pm 1.9^{* * *}$ \\
\hline & Fr-III & 6.3 & 0.03 & 8 & $31.4 \pm 3.2$ \\
\hline & Fr-IV & 45.8 & 0.23 & 8 & $40.0 \pm 1.7$ \\
\hline & Fr-V & 1.6 & 0.01 & 8 & $36.0 \pm 3.2$ \\
\hline \multicolumn{2}{|c|}{ Indomethacin } & & 0.01 & 8 & $18.5 \pm 1.6^{* * *}$ \\
\hline
\end{tabular}

Yield $(\%)$ indicated percentage of each yield obtained from the $n$-hexane soluble fraction. ${ }^{* * *} P<0.001$.

tions, only fraction- $11,0.19 \mathrm{~g} / \mathrm{kg}$, inhibited the increase of dye leakage induced by acetic acid. All of the other fractions did not inhibit the increase of dye leakage. The inhibitory potency induced by fraction-II was the same as that of $10 \mathrm{mg} / \mathrm{kg}$ of indomethacin.

Fraction-II. $0.19 \mathrm{~g} / \mathrm{kg}$, reduced the number of writhings induced by acetic acid. All of the other fractions did not significantly reduce the number of writhings. The inhibitory potency induced by fraction-II was the same as that of $10 \mathrm{mg} / \mathrm{kg}$ of indomethacin, as shown in Table 6.

4. Isolation of active principle from fraction-II: As only fraction-II showed the inhibitory effect on the increase of dye leakage induced by acetic acid, the active principle was isolated by using thin layer chroma- 
Table 7. Effect of fraction-VI and fraction-VII obtained from fraction-II and indomethacin on the increased vascular permeability induced by acetic acid

\begin{tabular}{ccccc}
\hline Compounds & $\begin{array}{c}\text { Yield } \\
(\%)\end{array}$ & $\begin{array}{c}\text { Dose } \\
(\mathrm{mg} / \mathrm{kg}, \mathrm{p} . \mathrm{o} .)\end{array}$ & $\begin{array}{c}\text { No. of } \\
\text { animals }\end{array}$ & $\begin{array}{c}\text { Amount of } \\
\text { leaked dye } \\
(\mu \mathrm{g} / \mathrm{animal})\end{array}$ \\
Control (2\% C.M.C.) & & 8 & $411.1 \pm 37.3$ \\
M. fragrans Fr-VI & 88.9 & 0.17 & 8 & $207.0 \pm 9.7^{* * *}$ \\
Indomethacin & 11.0 & 0.02 & 8 & $392.8 \pm 36.2$ \\
\hline
\end{tabular}

Yield (\%) indicated percentage of each yield obtained from fraction-ll. ***P<0.001.

tography (Kieselgel $60 \mathrm{~F}_{254}$. Merck). The solvent system used was benzene-chloroformethylacetate $(10: 10: 1)$. Spots on the plate were detected under ultraviolet light. As fraction-II showed a big spot (Fr-VI) and a very small spot ( $\mathrm{Fr}-\mathrm{VII})$ on the plate, the big spot was isolated $(R f=0.60)$ and it was obtained in a yield of $88.9 \%$. By using IR, UV, NMR and GC-Mass analyses, the chemical structure of fraction-VI was determined to be myristicin.

As shown in Table 7, myristicin ( $\mathrm{Fr}-\mathrm{VI}$ ) obtained from fraction- $11,0.17 \mathrm{~g} / \mathrm{kg}$, inhibited the increase of the dye leakage induced by acetic acid and the inhibitory potency induced by myristicin was the same as that of $10 \mathrm{mg} /$ $\mathrm{kg}$ of indomethacin.

\section{Discussion}

In the present study, it was found that the $70 \%$ methanol extract obtained from Mace, which has been used in Indonesian folk medicine as an analgesic and a medicine for rheumatism, inhibited the edema induced by carrageenin and inhibited the increase of dye leakage induced by acetic acid, and it also reduced the number of writhings induced by acetic acid. From these results, it seems likely that the extract of Mace has antiinflammatory and analgesic effects. Therefore, it was considered worthwhile to elucidate the antiinflammatory activity of the extract and to isolate the active principles from it.

The ether soluble fraction obtained from the methanol extract inhibited the edema induced by carrageenin and the increase of dye leakage induced by acetic acid and reduced the number of the writhings induced by acetic acid, but the water soluble fraction did not. As the antiinflammatory activity shifted to the ether soluble fraction, the ether soluble fraction was fractionated and monitored for antiinflammatory activity by determining the inhibition of the increase of dye leakage induced by acetic acid.

Among these fractions, the $n$-hexane soluble fraction, fraction-II and fraction-VI inhibited the increase of dye leakage induced by acetic acid. Fraction-ll also reduced the number of the writhings induced by acetic acid. As the potency of the inhibitory effects induced by these fractions was approximately the same as that of indomethacin in all experiments, it is considered that the antiinflammatory activity passed into fraction-II.

Then, the active principle was isolated from fraction-II using TLC in a yield of $88.9 \%$ (Fr$\mathrm{VI}$ ), and its chemical structure was identified as myristicin by comparison of UV, IR, NMR and GC-Mass spectra with this compound (16-25). Myristicin obtained from fraction-II inhibited the increase of the dye leakage induced by acetic acid.

These results suggest that the antiinflammatory effect of the methanol extract is due to the myristicin it contains and also myristicin may exert an analgesic effect.

It is well-known that the edema induced by carrageenin and the increase of vascular permeability induced by acetic acid are involved in the early exudative stage of inflammation, one of the important processes of inflammatory pathology (26-33). Myristicin inhibited the edema induced by carraggeenin and the increase of the vascular permeability induced by acetic acid, showing that it exerts the antiinflammatory effect at the early exudative stage of inflammation. 
It has been reported that Nutmeg, the seed of Myristica fragrans, and the whole Nutmeg oil which was obtained by steam distillation from it showed a stimulant effect on the central nervous system followed by a depressant effect and sometimes elicited a hallucinogenic effect, and myristicin was important in exerting these effects $(7-9,34)$. Brown et al. reported that centrally acting drugs inhibited the edema induced by carrageenin in the hind paw of the rats (26-28).

Although, myristicin, in the doses used in this experiment, has been found to be free from any apparent effect on the central nervous system in mice and rats, these reports suggest that the antiinflammatory effects of myristicin may be exerted partly through the central nervous system.

Assay of mediators in the inflammatory exudate produced by carrageenin in the rat showed the release of both histamine and bradykinin in the early phase, but that of prostaglandin $\mathrm{E}_{2}$ only after two to three hours (29-33). Moncada et al. reported that the carageenin induced edema was potentiated by prostaglandins $E_{1}$ and $E_{2}(32)$. It is well established that non-steroidal antiinflammatory drugs, indomethacin. sodium salicylate, ect. are generally potent inhibitors of prostaglandin biosynthesis and the inhibition of these drugs on prostaglandin biosynthesis played a prominant part in the antiinflammatory effect. Also, it was reported that myristicin inhibits prostaglandin biosynthesis (12).

From these reports, it is also considered that the antiinflammatory effect of myristicin may be exerted partly through the inhibition of prostaglandin biosynthesis.

Acknowledgment: This work was supported in part by a grant from the Special Coordinating Funds for Promoting Science and Technology (19841987) of the Science and Technology Agency of Japan.

\section{References}

1 Hirshhorn, H.H.: Botanical remedies of the former Dutch East Indies (Indonesia). Part I: Eumycetes, pteridophyta, gymnospermae, angiospermae (monocotyledones only). J. Ethnopharmacol. 7, 123-156 (1983)

2 Hirshhorn, H.H.: Botanical remedies of the former Dutch East Indies (Indonesia). Part II:
Dicotyledones up to and including leguminosae. J. Ethnopharmacol. 8, 65-96 (1983)

3 Elliott, S. and Brimacombe, J.: The medicinal plants of Gunung Leuser National Park, Indonesia. J. Ethnopharmaco!. 19, $285-317$ (1987)

4 Corner, E.J.H. and Watanabe, K.: Illustrated Guide to Tropical Plants. Hirokawa Publishing Co., Tokyo (1969) (in Japanese)

5 Perry, L.M.: Medicinal Plants of East and SouthEast Asia; Attributed Properties and Uses. MIT Press, Cambridge (United States) and London (1980)

$6 \mathrm{Hsu}, \mathrm{H} .-$ Y., Chen, Y.-P., Shen, S.-J., Hsu, C.-S., Chen, C.-C. and Chang, H.-C.: Orienta! Materia Medica; a Concise Guide. Oriental Healing Arts Institute, Long Beach (1986)

7 Truitt, E.B., Jr., Duritz, G. and Ebersberger, E.M.: Evidence of monoamine oxidase inhibition by myristicin and nutmeg. Proc. Soc. Exp. Biol. Med. 112, 647-650 (1963)

8 Shulgin, A.T.: Possible implication of myristicin as a phychotropic substance. Nature 23, 380384 (1966)

9 Sherry, C.J. and Burnett, R.E.: Enhancement cf ethano!-induced sleep by whole oil of nutmeg. Experientia 34, 492-494 (1978)

10 Sherry, C.J., Ray, L.E. and Herron R.E.: The pharmacological effects of a ligroin extract of nutmeg (Myristica fragrans). J. Ethnopharmacol. 6, 61-66 (1982)

11 Lichtenstein, E.P., Liang, T.T., Schulz, K.R., Schnoes. H.K. and Carter, G.T.: Insecticidal and synergistic compounds isolated from dill plants. J. Agr. Food Chem. 22, 658-664 (1974)

12 Rasheed, A., Laekeman, G.M., Vlietinck, A.J., Janssens J., Hatfield, G., Totte, J. and Herman, A.G.: Pharmacological influence of nutmeg and nutmeg constituents on rabbit platelet function. Planta Med. 50, 222-226 (1984)

13 Hattori, M., Hada, S., Watahiki, A., Ihara, H., Shu, Y.-Z., Kakiuchi, N., Mizuno, T. and Namba, T.: Studies on dental caries prevention by traditional medicines. $X$. Antibacterial action of phenolic components from mace against Streptococcus mutans. Chem. Pharm. Bull. (Tokyo) 34, 3885-3893 (1986)

14 Hattori, M., Hada, S., Shu, Y.-Z., Kakiuchi, N. and Namba, T.: New acyclic bis-phenylpropanoids from the aril of Myristica fragrans. Chem. Pharm. Bul!. (Tokyo) 35, 668-674 (1987)

15 Ozaki, Y., Soedigdo, S., Wattimena, J.R. and Suganda, A.G.: Antiinflammatory effect of Mace and its active principles. Japan. J. Pharmacol. 43, Supp. 103P (1987)

16 Bejnarowicz, E.A. and Kirch, E.R.: Gas chromato- 
graphic analysis of oil of nutmeg. J. Pharm. Sci. 52, 988-993 (1963)

17 Sammy, G.M. and Nawar, W.W.: Identification of the major components of nutmeg oil by gas chromatography and mass spectrometry. Chem. Ind. 38, 1279-1280 (1968)

18 Buttery, R.G., Seifert, R.M., Guadagni, D.G., Black, D.R. and Ling, L.C.: Characterization of some volatile constituents of carrots. J. Agr. Food Chem. 16, 1009-1015 (1968)

19 Harborne, J.B., Heywood, V.H. and Williams, C.A.: Distribution of myristicin in seeds of the umbelliferae. Phytochemistry 8, 1729-1732 (1969)

20 Kumamoto, J. and Scora, R.W.: The structure of sarisan, and isomer of myristicin, isclated from the leaf oil of Beilschmiedia miersii. J. Agr. Food Chem. 18, 544-545 (1970)

21 Sanford, K.J. and Heinz, D.E.: Effects of storage on the volatile composition of nutmeg. Phytochemistry 10, 1245-1250 (1971)

22 Forrest, J.E. and Heacock, R.A.: Identification of the major components of the essential oil of mace. J. Chromatogr. 69, 115-121 (1972)

23 Forrest, J.E., Heacock, R.A. and Forrest, T.P.: The isolation of dehydrodiisoeugenol from the aril of Myristica fragrans HOUTT. Experientia 29, 139 (1973)

24 Forrest, J.E. and Heacock, R.A.: A chromatographic comparison of the constituents of nutmeg and mace (Myristica fragrans HOUTT.) with those of marihuana and hashish (Cannabis sativa L.). J. Chromatogr. 89, 113-117 (1974)

25 Wulf, L.W., Nagel, C.W. and Branen, A.L.: Highpressure liquid chromatographic separation of the naturally occurring toxicants myristicin, related aromatic ethers and falcarinol. J. Chromatogr. 161, 271-278 (1978)
26 Winter, C.A., Risley, E.A. and Nuss, G.W.: Carrageenin induced edema in hind paw of the rats as an assay for antiinflammatory drugs. Proc. Soc. Exp. Biol. Med. 111, 544-547 (1962)

27 Whittle, B.A.: The use of changes in capillary permeability in mice to distinguish between narcotic and nonnarcotic analgesics. Br. J. Pharmacol. 22, 246-253 (1964)

28 Brown, J.H., Kissel, J.W. and Lish, P.M.: Studies on the acute inflammatory response. I. Involvement of the central nervous system in certain models of inflammation. J. Pharmacol. Exp. Ther. 160, 231-242 (1968)

29 Marriet, M.H., Webster, M.E., Wiilliams, M.A., Saul, W. and Anderson, W.: Inflammation induced by histamine, serotonin, bradykinin and compound 48/80 in the rat: Antagonists and mechanisms of action. J. Pharmacol. Exp. Ther. 191, 300-310 (1974)

30 Bhargava, K.P., Nath, R. and Palit, G.: Nature of histamine receptors concerned in capillary permeability. Br. J. Pharmacol. 59, 349-351 (1977)

31 Willis, A.L.: Parallel asay of prostaglandin-like activity in rat inflammatory exudate by means of cascade superfusion. J. Pharm. Pharmacol. 21, 126-128 (1969)

32 Moncada, S., Ferreira, S.H. and Vane, J.R.: Prostaglandins, aspirin-like drugs and the oedema of inflammation. Nature 246, 217-219 (1973)

33 Bonta, I.L., Bult, H. and Parnham, M.J.: The presence of prostaglandin-like material in carrageenin induced rat hind paw inflammation. $\mathrm{Br}$. J. Pharmacol. 60, 290P (1977)

34 Kalbhen, D.A.: Nutmeg as a narcotic. Angew. Chem. Int. Edit. 10, 370-374 (1971) 